\title{
Alumina Supported Iron Catalyst for Hydrogen Production: Calcination Study
}

\author{
Anis Fakeeha ${ }^{1}$, Wasim Khan ${ }^{* 1}$, Ahmed Ibrahim ${ }^{1}$, Raja Al-Otaibi ${ }^{2}$, Ahmed Al-Fatesh ${ }^{1}$, \\ Moustafa Soliman ${ }^{3}$ and Ahmed Abasaeed ${ }^{1}$
}

\begin{abstract}
Production of clean hydrogen from thermal decomposition of methane was studied over impregnated $30 \% \mathrm{Fe} / \mathrm{Al} 2 \mathrm{O} 3$ catalysts in a micro-activity fixed-bed reactor. The reactant gases comprising $\mathrm{CH} 4$ and $\mathrm{N} 2$ in the ratio of 1.5 to 1 were passed through reactor at a flow rate of $25 \mathrm{~mL} / \mathrm{min}$. Moreover, effect of calcination was investigated as well. The catalytic activity results indicated that calcination temperature had a significant impact on the performance of $30 \% \mathrm{Fe} / \mathrm{Al} 2 \mathrm{O} 3$ catalyst. The catalyst calcined at $450^{\circ} \mathrm{C}$, having $\mathrm{CH} 4$ conversion as well as $\mathrm{H} 2$ yield over $70 \%$, showed better activity as compared to all other calcination temperatures.
\end{abstract}

Keywords - Hydrogen, Iron, CH4.

\section{INTRODUCTION}

$\mathrm{W}$ ELCOME Hydrogen, a clean energy fuel, can be taken as a demanding alternative to conventional fossil fuels in order to reduce $\mathrm{CO}_{2}$ emissions [1-3]. Fossil fuels are generally accepted as a source for hydrogen production in the near future. Hydrocarbon reforming has been widely used so far for the production of hydrogen using metal based catalysts including $\mathrm{Ni}, \mathrm{Cu}$ and $\mathrm{Co}$ but reforming leads to $\mathrm{CO}_{2}$ generation which needs to be captured to make the reforming process clean [4-8].

Hydrogen production near to its utilization place through small to medium decentralized installations would minimize the risks involved in hydrogen transport. Hydrogen production via methane reforming in these installations may significantly increase the cost of hydrogen production as $\mathrm{CO}_{2}$ needs to be transported to sink. Therefore, catalytic decomposition of methane $(\mathrm{CDM})$ to hydrogen gas and solid valuable carbon can be considered a very interesting alternative to methane reforming [9].

Several factors including active metal, support, preparation method, calcination and activation temperatures significantly affect the catalytic performance during CDM. Pudukudy et al [10] studied the Thermocatalytic decomposition of methane as an alternative route for the production of COx-free hydrogen and carbon nanomaterials. They used bimetallic catalysts that include iron supported over mesoporous SBA-15. The results showed that the bimetallic catalysts were highly active and

\footnotetext{
${ }^{1}$ Chemical Engineering Department, College of Engineering King Saud University P.O. Box 800, Riyadh 11421, Kingdom of Saudi Arabia,

${ }^{2}$ King Abdulaziz City for Science and Technology (KACST)

${ }^{3}$ British University in Egypt, *Corresponding Author: +966567948527; Email: wasimkhan49@gmail.com
}

stable for the reaction at $700^{\circ} \mathrm{C}$ even after 300 min of time on stream (TOS). Formation of bimetallic alloys is related to the catalytic stability. Ibrahim et al. [11] investigated the decomposition of methane by iron catalyst to produce hydrogen and carbon. The catalysts were calcined at $700^{\circ} \mathrm{C}$ and reduced with pure $\mathrm{H}_{2}$ at $650^{\circ} \mathrm{C}$. The reaction was carried out at $700^{\circ} \mathrm{C}$. The study involved the use of different iron loadings supported on alumina catalysts obtained by coprecipitation technique. The catalyst characterization revealed the formation of multiwalled nanotubes from alumina supported iron catalyst. Alternatively, time on stream tests of the supported catalyst for about $4 \mathrm{~h}$ at $700^{\circ} \mathrm{C}$ showed the relative profile of hydrogen production and hydrogen yield increased as the \% loading of $\mathrm{Fe}$ was increased. A maximum $\mathrm{H}_{2}$ yield of $77.2 \%$ was obtained using $60 \% \mathrm{Fe} / \mathrm{Al}_{2} \mathrm{O}_{3}$ catalyst. Higher Fe loadings decreased the surface area of the catalyst.

In this paper, we have investigated the effect of calcination temperature over impregnated $30 \% \mathrm{Fe} / \mathrm{Al}_{2} \mathrm{O}_{3}$ catalysts. Catalyst characterizations have been employed to study the behavior of catalyst before and after reaction. Moreover, a short description related to effect of activation temperature over impregnated $30 \% \mathrm{Fe} / \mathrm{Al}_{2} \mathrm{O}_{3}$ catalyst has been added as well.

\section{EXPERIMENTAL AND PROCEDURES}

\section{A. Catalyst Preparation and Testing}

The wet-impregnation method was used to prepare the catalysts and the total $\mathrm{Fe}$ loading with all catalysts were fixed at 30 wt $\%$ with respect to $\mathrm{Al}_{2} \mathrm{O}_{3}$ support. In a typical wetimpregnation process, the solution having a stoichiometric amount of iron nitrate nona-hydrate $\left[\mathrm{Fe}\left(\mathrm{NO}_{3}\right)_{2} .9 \mathrm{H}_{2} \mathrm{O}\right]$ was prepared using double distilled water. Afterwards respective supports were added to the solution with constant stirring at 85 ${ }^{\circ} \mathrm{C}$ Then catalysts were dried at $120{ }^{\circ} \mathrm{C}$ for about $13 \mathrm{~h}$, followed by calcination at different temperatures i.e., 50, 500, 550 and $600{ }^{\circ} \mathrm{C}$ in atmospheric air for $3 \mathrm{~h}$.

The prepared catalysts were tested in a micro-activity fixed bed tubular reactor $(10 \mathrm{~mm}$ ID) coupled with K-type thermocouple using $0.3 \mathrm{~g}$ of the catalyst at different reaction temperatures and space velocities. Prior to $\mathrm{CDM}$ reaction, each catalyst was first reduced under $\mathrm{H}_{2}$ flow $(40 \mathrm{~mL} / \mathrm{min})$ at $500^{\circ} \mathrm{C}$ for $90 \mathrm{~min}$. The products of the reactor were analyzed by using an online GC (Varian Star $3400 \mathrm{cx}$; Ar as carrier) equipped with a thermal conductivity detector and a gas sampling valve. 


\subsection{Catalyst Characterization}

The specific surface area of the catalysts was determined from N2 adsorption-desorption data at $-196 \square \mathrm{C}$ by using a Micromeritics Tristar II 3020 surface area and porosity analyzer. For each analysis, $0.3 \mathrm{~g}$ of catalyst was degassed at $300 \square \mathrm{C}$ for $3 \mathrm{~h}$ to rid the catalyst surface from moisture content and other adsorbed gases.

The TPR measurements were completed on a chemisorption apparatus (Micromeritics Auto Chem II apparatus) using 70 $\mathrm{mg}$ for each sample. The samples were pretreated with high purity Argon (Ar) flowing at $150^{\circ} \mathrm{C}$ for $30 \mathrm{~min}$, followed by cooling to room temperature and then heating in a furnace up to $1000^{\circ} \mathrm{C}$ with a constant heating rate of $10^{\circ} \mathrm{C} / \mathrm{min}$ using a $\mathrm{H} 2 / \mathrm{Ar}$ mixture flowing at a rate of $40 \mathrm{~mL} / \mathrm{min}$ (volume ratio, 10/90). The signal of $\mathrm{H} 2$ consumption was monitored by a thermal conductivity detector (TCD).

\section{RESULTS AND DISCUSSIONS}

The calcination step perhaps has the most influence on the properties of the prepared catalyst. Selection of proper calcination temperature is of extreme importance in the preparation methods of catalysts. Fig. 1 shows the $\mathrm{N}_{2}$ partial pressure adsorption during the measurements of surface area for $30 \% \mathrm{Fe} / \mathrm{Al}_{2} \mathrm{O}_{3}$ catalyst at different calcination temperatures. The quantity of the gas adsorbed increases with the increase of the partial pressure for all calcination temperatures. However, the catalyst calcined at $600^{\circ} \mathrm{C}$ adsorbs the most amount of $\mathrm{N}_{2}$ and hence gives the highest surface area (BET), but the catalyst calcined at $500^{\circ} \mathrm{C}$ indicated relatively the highest BET instead of that calcined at $600^{\circ} \mathrm{C}$.

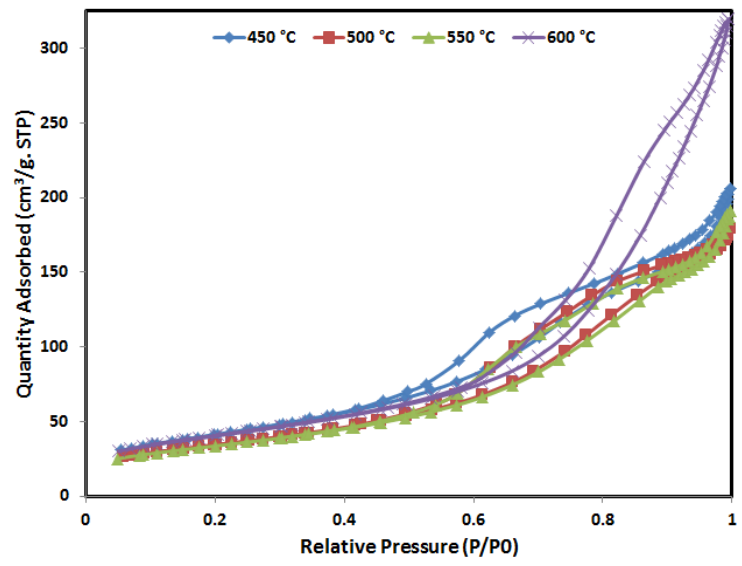

Fig. $1 \mathrm{~N}_{2}$ adsorption-desorption isotherms for fresh $30 \% \mathrm{Fe} / \mathrm{Al}_{2} \mathrm{O}_{3}$ Imp catalysts series at different calcination temperatures.

\section{UNITS}

Fig. 2 displays the TPR curves of $30 \% \mathrm{Fe} / \mathrm{Al} 2 \mathrm{O} 3$ catalysts calcined at 450, 500, 550 and $600 \square \mathrm{C}$. TPR patterns for different calcined catalysts are rather alike to each other stipulating that catalysts have experienced thoroughly similar reduction behavior. The response of temperature scans using hydrogen as reducing agent provides three peaks in the TPR profiles. Their signals appear around 250-460, 484-810, 835$945^{\circ} \mathrm{C}$ with maximum peaks centered at 400,710 and $898^{\circ} \mathrm{C}$ respectively. These regions of temperature obviously identify that catalytic methane decomposition follows three mechanisms that are predominant at different temperatures. The first peak is ascribed to the transformations of $\mathrm{FeOOH} \rightarrow$ $\mathrm{Fe} 2 \mathrm{O} 3$ while the second peak is attributed to the reduction of $\mathrm{Fe} 2 \mathrm{O} 3 \rightarrow \mathrm{Fe} 3 \mathrm{O} 4$, and third peak is assigned to $\mathrm{Fe} 3 \mathrm{O} 4 \rightarrow \mathrm{Fe}$. Here, again the response peaks of $450^{\circ} \mathrm{C}$ calcined catalyst are clearly mostly shifted to lower temperature reduction showing easiest reduction behavior. While the catalyst calcined at $550^{\circ} \mathrm{C}$ indicates the strongest metal support interactions and therefore its response appears fairly at highest reduction temperature.

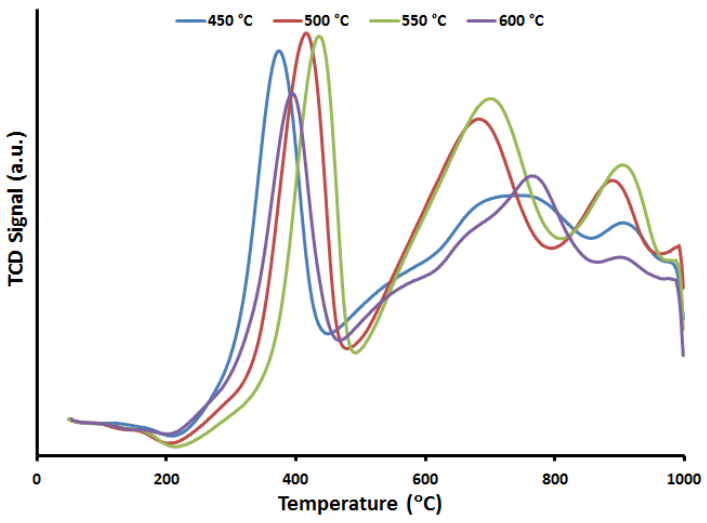

Fig. 2 TPR profiles for $30 \% \mathrm{Fe} / \mathrm{Al}_{2} \mathrm{O}_{3}$ catalyst prepared by impregnation

On the other hand, Fig. 3 exhibits the time on stream methane conversions of $30 \% \mathrm{Fe} / \mathrm{Al}_{2} \mathrm{O}_{3}$ catalysts prepared by impregnation method, calcined at $450,500,550$ and $600^{\circ} \mathrm{C}$ and operated at $700^{\circ} \mathrm{C}$. It is evident that the conversion increases and remains constant after an hour. The catalysts calcined at $450^{\circ} \mathrm{C}$ gives the best performance of conversion and stability. The trend of conversion is similar to that of Fig. 3 . However, the stability of the best catalyst, catalyst calcined at $450^{\circ} \mathrm{C}$, becomes constant after 90 minutes. Fig. 4 shows the time on stream against hydrogen yield for $30 \% \mathrm{Fe} / \mathrm{Al}_{2} \mathrm{O}_{3}$ catalysts prepared by impregnation method, calcined at 450 , 500,550 and $600^{\circ} \mathrm{C}$ and operated at $700^{\circ} \mathrm{C}$. Catalyst calcined at $450^{\circ} \mathrm{C}$ tops in yield and stability than all other catalysts right from the initial period.

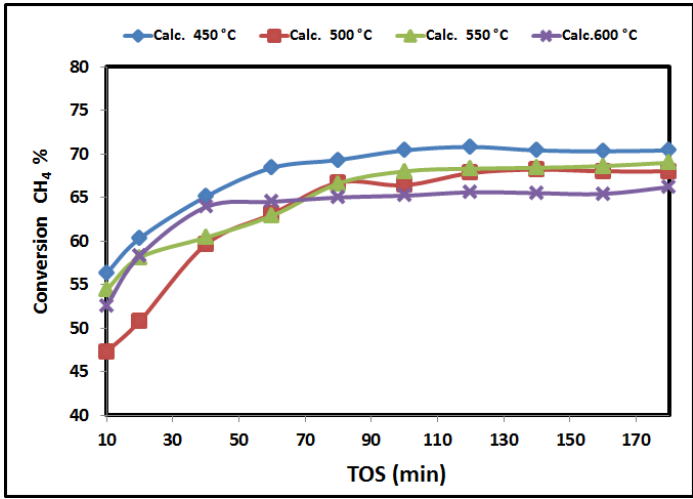

Fig. 3 Time on stream conversion of methane for different calcinations for $30 \% \mathrm{Fe} / \mathrm{Al}_{2} \mathrm{O}_{3}$ catalyst at $700^{\circ} \mathrm{C}$. 


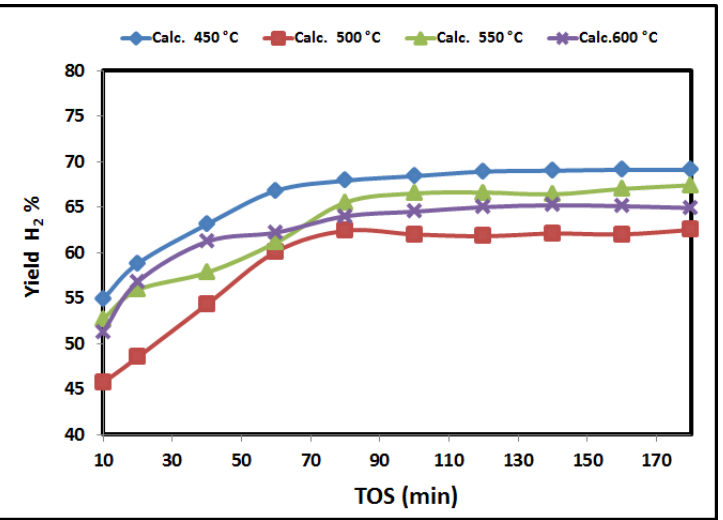

Fig. 4 Time on stream yield of hydrogen for different calcinations for $30 \% \mathrm{Fe} / \mathrm{Al}_{2} \mathrm{O}_{3}$ catalyst at $700^{\circ} \mathrm{C}$.

\section{CONCLUSIONS}

Clean hydrogen production from methane decomposition reaction was investigated over impregnated $30 \% \mathrm{Fe} / \mathrm{Al}_{2} \mathrm{O}_{3}$ catalyst. Furthermore, effect of calcination temperature was studied as well. The catalytic performance results showed that catalyst calcined at $450^{\circ} \mathrm{C}$ exhibited better activity, in terms of $\mathrm{CH}_{4}$ conversion as well as $\mathrm{H}_{2}$ yield, as compared to the rest of the catalysts.

\section{ACKNOWLEDGEMENTS}

The authors thankfully acknowledge their appreciation to King Abdulaziz City for Science and Technology (KACST) for funding the work through the research project \# AT-34-4.

\section{REFERENCES}

[1] F. A. Coutelieris, S. Douvertzides and P. Tsiakaras, "The importance of the fuel choice on the efficiency of a solid oxide fuel cell system", $J$. Power Sources, vol., 123, pp. 200-205, September 2003. http://dx.doi.org/10.1016/S0378-7753(03)00559-7

[2] R. Peters, R. Dahl, U. Klüttgen, C. Palm and D. Stolten, "Internal reforming of methane in solid oxide fuel cell systems", J. Power Sources, vol., 106, pp. 238-244, April 2002. http://dx.doi.org/10.1016/S0378-7753(01)01039-4

[3] J. Meusinger, E. Riensche and U. Stimming, "Reforming of natural gas in solid oxide fuel cell systems", J. Power Sources, vol., 71, pp. 315322, March 1998. http://dx.doi.org/10.1016/S0378-7753(97)02763-8

[4] S. Freni, S. Cavallaro, N. Mondello, L. Spadaro and F. Frustreri, "Steam reforming of ethanol on $\mathrm{Ni} / \mathrm{MgO}$ catalysts: $\mathrm{H} 2$ production for MCFC", J. Power Sources, vol., 108, pp. 53-57, June 2002. http://dx.doi.org/10.1016/S0378-7753(02)00004-6

[5] F. Pompeo, N. N. Nichio, M. G. González and M. Montes, "Characterization of $\mathrm{Ni} / \mathrm{SiO}_{2}$ and $\mathrm{Ni} / \mathrm{Li}-\mathrm{SiO}_{2}$ catalysts for methane dry reforming", Catal. Today, vol., 107-108, pp. 856-862, October 2005. http://dx.doi.org/10.1016/j.cattod.2005.07.024

[6] S. Rakass, H. Oudghiri-Hassani, P. Rowntree and N. Abatzoglou, "Steam reforming of methane over unsupported nickel catalysts", $J$. Power Sources, vol., 158, pp. 485-496, July 2006. http://dx.doi.org/10.1016/j.jpowsour.2005.09.019

[7] S. Patel and K. K. Pant, "Activity and stability enhancement of copperalumina catalysts using cerium and zinc promoters for the selective production of hydrogen via steam reforming of methanol", J. Power Sources, vol., 159, pp. 139-143 September 2006. http://dx.doi.org/10.1016/j.jpowsour.2006.04.008

[8] A. Fonseca Lucrédito and E. Moreira Assaf, "Cobalt catalysts prepared from hydrotalcite precursors and tested in methane steam reforming", $J$. Power Sources, vol., 159, pp. 667-672, September 2006. http://dx.doi.org/10.1016/j.jpowsour.2005.10.108
[9] N. Z. Muradov and T. N. Veziroglu, "From hydrocarbon to hydrogencarbon to hydrogen economy", Int. J. Hydrogen Energy, vol., 30, pp. 225-237, March 2005. http://dx.doi.org/10.1016/j.ijhydene.2004.03.033

[10] M. Pudukudy and Z. Yaakob, "Methane decomposition over Ni, Co and Fe based monometallic catalysts supported on sol gel derived $\mathrm{SiO}_{2}$ microflakes", Chem. Eng. J., vol., 262, pp. 1009-1021, February 2015. http://dx.doi.org/10.1016/j.cej.2014.10.077

[11] A. A. Ibrahim, A. H. Fakeeha, A. S. Al-Fatesh, A. E. Abasaeed and W. U. Khan, "Methane decomposition over iron catalyst for hydrogen production", Int. J. Hydrogen Energy, vol., 40, pp. 7593-7600, June 2015. http://dx.doi.org/10.1016/j.ijhydene.2014.10.058

[12] C. Pirola, C. L. Bianchi, A. D. Michele, S. Vitali and V. Ragaini, "Fischer Tropsch and Water Gas Shift chemical regimes on supported iron-based catalysts at high metal loading", Catal. Commun., vol., 10, pp. 823-827, February 2009.

[13] W. K. Jozwiak, E. Kaczmarek, T. P. Maniecki, W. Ignaczak and W. Maniukiewicz, "Reduction behavior of iron oxides in hydrogen and carbon monoxide atmospheres", Appl. Catal. A: Gen., vol., 326, pp. 1727 June 2007. 